Cahiers de recherches médiévales

\title{
Antiquarian Arthur
}

Publishing the Round Table in Sixteenth-Century France

Jane H. M. Taylor

\section{CpenEdition}

\section{Journals}

Electronic version

URL: https://journals.openedition.org/crm/2663

DOI: $10.4000 / \mathrm{crm} .2663$

ISSN: 1955-2424

Publisher

Honoré Champion

\section{Printed version}

Date of publication: 15 December 2007

Number of pages: 127-142

ISSN: $1272-9752$

Electronic reference

Jane H. M. Taylor, "Antiquarian Arthur", Cahiers de recherches médiévales [Online], 14 | 2007, Online since 30 November 2009, connection on 15 December 2022. URL: http://journals.openedition.org/ crm/2663 ; DOl: https://doi.org/10.4000/crm.2663 


\section{酷M}

\section{Antiquarian Arthur : Publishing the Round Table in Sixteenth- Century France}

Antoine Vérard, on whom I shall concentrate in this paper, is, says Eugénie Droz, a businessman, "avant tout un marchand», with an excellent eye for what would appeal to a public consisting not just of the usual, more aristocratic or courtly readers, but also of bourgeois ${ }^{1}$. One of his many mercantile gifts was, it seems, the ability to judge just which of the existing repertory of texts might bring him most success - and important among those texts was the French medieval literature that he did so much to popularise ${ }^{2}$ : from moralités to moralising, from the Cent nouvelles nouvelles in 1486 to the compendium he calls the Jardin de Plaisance in 1501. ${ }^{3}$ In commercial terms, and given the expense of publishing and the distinct danger of bankruptcy ${ }^{4}$, it is remarkable that he was also the publisher of a string of vast, intractable prose works: universal histories like the Miroir historial, the chronicles of Froissart and Monstrelet - and chivalric romances : Ogier le danois in 1498 , Tristan en prose in 1489, and, my prime subject here, the Lancelot en prose in 14945 .

This latter was not, as it happens, the first printed edition of the Lancelot: the editio princeps was published in 1488, and was the work of Le Bourgeois in Rouen and Jean Du Pré of Paris - although Pickford, and now Winn, suggest that Vérard may, anonymously, have helped in its production, on the persuasive grounds that it

1 «Notice sur un recueil de louanges", Romania, 49, 1923, 48-62 (p. 62). More than 280 volumes, published between 1485 and 1512, give his name as publisher or printer. On his remarkable career, see J. Macfarlane, Antoine Vérard, London, Bibliographical Society at the Chiswick Press, 1900 ; repr. Geneva, Slatkine, 1971, and cf. most recently the magnificent book by M. B. Winn, Anthoine Vérard, Parisian Publisher, 1485-1512 : Prologues, Poems and Presentations, Geneva, Droz, 1997.

2 As A. Claudin remarks, «aucun libraire n'a publié autant de livres illustrés, aucun n'a vulgarisé davantage notre littérature nationale»: Histoire de l'imprimerie en France au $X V^{e}$ et au XVI siècle, Paris, Imprimerie Nationale, 1900-14 ; repr. Nendeln, Kraus, 1971, t. II, p. 506.

3 For details of Vérard's editions, see Macfarlane, Antoine Vérard, supplemented by Winn, Anthoine Vérard, p. 490-504.

4 C. Bühler, The Fifteenth-Century Book: The Scribes, the Printers, the Decorators, Philadelphia, University of Pennsylvania Press, 1960, p. 59-61, is interesting the number of printers who failed to assess their markets shrewdly enough, or who printed more copies than fifteenth-century distribution networks made wise. Vérard, by contrast, was highly successful financially (see Winn, Anthoine Vérard, ch. 1), able to buy substantial properties, and to maintain links with the royal court.

${ }_{5}^{5}$ Winn, Anthoine Vérard, devotes a section to the Lancelot: see p. 295-313. She uses two copies in the Bibliothèque nationale de France: BnF Rés. Vélins 614, and BnF Rés. Vélins 617-619. Unfortunately, I was unable to obtain microfilms of these editions, and I am very grateful to the Bibliothèque Municipale de Lyon for furnishing me with a copy on CDRom.

Cahiers de Recherches Médiévales, 14, 2007 
would have taken a major printing house to finance so immense an undertaking. But Vérard's enterprise of 1494 is on a rather different scale: there is a profusion of woodcuts, ${ }^{6}$ copies were printed on vellum 7 , for presentation to wealthy patrons, two of them with cuts overpainted in the style of what Dominique Coq calls a "manuscrit-imprimé ${ }^{8}$ : that is, painted to resemble an illuminated manuscript, and designed for the vital royal patronage of Charles VIII. The implication is that Vérard - encouraged, perhaps, by the reception of the earlier 1488 edition - was convinced of a favourable reception for his Lancelot: that he judged it bound to appeal not just to the taste of the prosperous wider audience but also to the refined and discriminating taste of the royal court. But Vérard's success as a publisher is no accident: everything suggests that he judged the taste of the time and the opportunities for profit with remarkable business acumen. It is the purpose of this paper to continue the exploration of some of the ways in which a canny merchant in the early days of printing «packaged» the Lancelot en prose precisely to appeal to new audiences\%. I shall argue, in particular, that the rather complicated history of Vérard's paratextual apparatus for this volume, properly interpreted, allows us to follow what we might call his "sales strategy", in ways which illuminate the

\footnotetext{
${ }^{6}$ Many admittedly recycled throughout the edition - a not infrequent economy measure, of course, in early printing.

7 Although no accounts have survived for the Lancelot, we do, interestingly, have a copy of the quite exorbitant bill sent by Verard to the comte d'Angoulême for the preparation of a presentation copy of the first volume only of the Tristan en prose : it includes the costs of parchment, full-page miniatures, smaller column-width miniatures, gold lettering and a tooled binding. The grand total is a startling $£ 7416 \mathrm{~s} 8 \mathrm{p}$ (see Macfarlane, Antoine Vérard, p. 129-31). 8 "Les incunables : textes anciens, textes nouveaux», Histoire de l'édition française, éd. R. Chartier and H.-J. Martin, Paris, Promodis, 1989-91, t. I, 203-27 (p. 219), and cf. on Vérard's predilection for such manuscripts Winn, «Offerings for the King : Antoine Vérard's Presentation Manuscripts and Printed Books", Manuscripts in the Fifty Years after the Invention of Printing, ed. J. B. Trapp, London, Warburg Institute, 1983, p. 66-74. For both of them, it is true, the true manuscrits-imprimés are the carefully adapted and coloured productions that Vérard presented to royal and other patrons - but page layout in general, and in particular the use of woodcuts and initials, make volumes like the Lancelot strikingly manuscriptural: see the two royal presentation copies, BnF Rés. Vélins 614-616, and BnF Rés. Vélins 617-619 (which also, incidentally, include specially commissioned presentation miniatures to which I return later in this paper).

${ }_{9} \mathrm{Ph}$. Ménard has called for precisely this sort of exploration; see his «La réception des romans de chevalerie à la fin du Moyen Âge et au XVI ${ }^{\mathrm{e}}$ siècle», Bibliographical Bulletin of the International Arthurian Society, 49, 1997, 234-73, and more recently, briefly, «Trente ans d'études arthuriennes", Trente ans de recherches en langues et en littératures médiévales, éd J.-R. Valette : Perspectives médiévales, mars 2005, 337-65 (esp. 364-65). I am not the first, of course, to address these questions : see in particular C. Pickford, «Les éditions imprimées de romans arthuriens en prose antérieurs à $1600 »$, Bibliographical Bulletin of the International Arthurian Society, 13, 1961, 99-109 and id., "Antoine Vérard: Editeur du Lancelot et du Tristan »; N. Cazauran, «Les romans de chevalerie en France : entre exemple et recréation », Le Roman de chevalerie au temps de la Renaissance, éd. M. T. Jones-Davies, Paris, J. Touzot, 1987, p. 29-45 ; Winn, Anthoine Vérard, 295-313.
} 
business practices of early printers like Vérard, venturing into an unfamiliar and economically dangerous world ${ }^{10}$.

I have just referred to the « rather complicated history » of Vérard's Lancelot; let me outline, briefly, what I meant. As I pointed out, there exists a previous edition of the Lancelot en prose, dating from 1488 and the work of two printing houses, possibly, though unverifiably, in conjunction with Vérard: volume 1 was issued in November 1488 by the brothers Jehan and Gaillard Le Bourgeois, from Rouen; volume 2, slightly earlier, by the Parisian printer Jehan du Pré11. This edition must have sold sufficiently well for Vérard to publish an edition under his own imprint in 1494 ; a second edition of this latter publication was produced, subsequently, in $1504^{12}$. Both the 1488 print and Vérard's edition are prefaced by a sizeable prose prologue, the latter copying, wholesale, considerable segments of the first, that by du Pré and Le Bourgeois. Whether or not this is a matter of plagiarism - whether, that is, Vérard himself produced the prologue for the edition of 1488 and simply adapted it for his new edition of 1494, or whether he was plagiarising his predecessors of $1488^{13}$ - is largely immaterial: the salient point is that by comparing the two prologues, we can follow some of the processes whereby «sales strategies» were developed for each of the editions : how the printer(s) selected elements of the 1488 prologue, and rephrased and rebalanced them, in ways which suggest the allurements which, they must have hoped, would persuade new clients to buy expensive, indeed in the case of the 1494 imprint, luxurious editions ${ }^{14}$. In addition, in

${ }^{10}$ I emphasise, of course, the remarkable work done on this very text by Winn, Anthoine Vérard, p. 295-310; her approach is a little different from mine, but her pioneering chapter is a model of analysis.

11 A facsimile of this edition was published by C. E. Pickford, London, The Scolar Press, 1977, from the copy in the National Library of Wales. For brief comments, see his «Les éditions imprimées $»$.

${ }^{12}$ Vérard clearly had high hopes for his romance : he printed at least six copies on vellum (see Winn, Anthoine Vérard, p. 301, footnote 6). And it was, clearly, very popular: A. H. Schutz, Vernacular Books in Parisian Private Libraries of the Sixteenth Century According to Notarial Inventories, Chapel Hill, University of North Carolina Press, 1955, finds no fewer than 21 copies in inventories in the notorial archives of Paris; A. Labarre, Le Livre dans la vie amiénoise du seizième siècle : l'enseignement des inventaires après décès, Paris/Louvain, Nauwelaerts, 1971, finds three - which are figures that suggest a remarkably rich total when compared with other, roughly comparable, texts. The romance was republished in editions based on Vérard's in the course of the sixteenth century: by Michel Le Noir in 1513 and 1520, by Philippe Le Noir in 1533, and in a much-abbreviated version by Benoist Rigaud in 1591 (on the last of which, see C. E. Pickford, «Benoist Rigaud et le Lancelot du Lac de $1591 »$, Mélanges Jean Frappier, Geneva, Droz, 1970, t. II, p. 903-11).

${ }^{13}$ And Vérard was not, of course, like most early printers, averse to a little plagiarism here and there: see M. B. Winn, «Publisher vs. Author: Anthoine Vérard, Jean Bouchet, and L'amoureux transy » Bibliothèque d'Humanisme et Renaissance, 50, 1988, 667-80, and cf. C. J. Brown, Poets, Patrons and Printers : Crisis of Authority in Late Medieval France, Ithaca, Cornell University Press, 1995.

14 On the ways in which early publishers designed prefaces, artfully, for their intended readership - and which suggests a sensitivity to potential audiences - see Brown, Poets, 
one surviving copy only of the edition of 1494, this one intended for presentation to Charles VIII ${ }^{15}$, Vérard included a novelty which, as Mary Beth Winn says, he uses nowhere else16: a second, verse prologue, in 43 decasyllables, rather convoluted because of the need to conform to acrostic first letters reading CHARLES DE VALOIS ROY DE FRANCE HUITIESME DE CE NOM ${ }^{17}$, but the analysis of which suggests the ways in which Vérard hoped, for this deluxe volume, to attract specifically royal favour and patronage. What I propose to do, here, is to examine each of these prologues, in search of what it is, I think, not unreasonable to think of as their « sales pitch $» .^{18}$.

Take first, then, the unusually long, and, it must be said, rather laboured prologue to the edition of 1488 (Appendix I), which may or may not have been, as we have seen, the work of Vérard himself. Its opening few lines (A-B), briefly, make the following promises as to the content of the volumes ${ }^{20}$ :

i. Veracity: the anciennes histoires, the writer of the prologue concedes, are not holy writ, but that does not mean that they are not

Patrons, and Printers, A. Armstrong, Technique and Technology : Script, Print and Poetics in France 1470-1550, Oxford, Clarendon Press, 2000, and H. S. Bennett, English Books and Readers, 1475-1557, Cambridge, Cambridge University Press, 1952, p. 16-17.

15 This is BnF, Rés. Vélins 614.

${ }^{16}$ Anthoine Vérard, p. 299 and 305.

${ }^{17}$ A device Vérard also uses for an encomium of Charles printed as an epilogue in his edition of Molinet's Art et science de rhetorique (Paris, BnF Rés. Vélins 577) : published by Winn, Anthoine Vérard, p. 95, note 33, and cf. Brown, Poets, Patrons, and Printers, p. 119, 159.

${ }^{18} \mathrm{~F}$. Rigolot calls the preface a «vestibule initiatique »; that is, the mode by which the writer inducts readers into his specific project: «Prolégomènes à une étude du statut de l'appareil liminaire des textes littéraires », L'Esprit créateur, 27, 1987, 7-18 (7). On the prologues to early printed Arthuriana, see Danielle Bohler, «Le lecteur inscrit dans le projet du livre : le roman chevaleresque et son prologue, du manuscrit aux imprimés ", in Le Goût du lecteur à la fin du Moyen Âge, éd Danielle Bohler, Cahiers du Léopard d'Or, 11 (2006), 293-305.

${ }^{19}$ On the role of the prologue, see the unusually interesting contribution by R. Evans : «An Afterword on the Prologue», The Idea of the Vernacular: An Anthology of Middle English Literary Theory 1280-1520, ed. J. Wogan-Browne, N. Watson, A. Taylor and R. Evans, Exeter, University of Exeter Press, 1999, p. 371-78. Most of the material anthologised in the volume as a whole is from prologues to Middle English texts; something equivalent is much needed for French, although the need is partially met by a volume edited by E. Baumgartner and L. Harf-Lancner, Seuils de l'oeuvre dans le texte médiéval, 2 vols (Paris: Presses de la Sorbonne, 2002).

${ }^{20}$ On the role of the prologue, see the unusually interesting contribution by R. Evans : «An Afterword on the Prologue », The Idea of the Vernacular: An Anthology of Middle English Literary Theory 1280-1520, ed. J. Wogan-Browne, N. Watson, A. Taylor and R. Evans, Exeter, University of Exeter Press, 1999, p. 371-78. Most of the material anthologised in the volume as a whole is from prologues to Middle English texts; something equivalent is much needed for French, although the need is partially met by a volume edited by E. Baumgartner and L. Harf-Lancner, Seuils de l'oeuvre dans le texte médiéval, 2 vols (Paris : Presses de la Sorbonne, 2002). 
veritables - and of course the mere fact that he mobilises divines escriptures as a comparator implies reliability.

ii. Great deeds (vertus et glorieux faiz) : the pagans actually deified their hommes vertueux; the writer considers it decent et raisonnable therefore to celebrate more modern heroes, either with carved memorials or, as here, in words.

iii. Inspiration (excitation de bien et vertueusement vivre), in pursuit of eternal fame.

iv. Moral lessons: mauvais and vicieux receive appropriate punishment.

v. In general, examples to follow or to avoid: as St Paul says, we can draw lessons from anything that we read ....

The writer then goes on (C) to a new topic, one carefully conceived as a justification for the writer's avocation. There are, he says, those whose gift is words and who have devoted their lives to developing their intellectual faculties; there are those who have distinguished themselves in prouesses et chevaleries, and who are deserving, therefore, of the efforts of the first group to ensure that their deeds are perpetuated for the edification of jeunes nobles bacheliers desirans florir en renommee chevalereuse. Which brings the writer to the next topic (D): his own qualifications for the arduous task he is setting himself. He is, he agrees - a standard modesty topos - des hystoriographes le mendre, but he has read the anciennes escriptures exhaustively, and been able therefore to select for presentation to his readers of 1488 ; bombarded with material from all sides, he has devoted l'encre de [s]on entendement to those parts of it which are plus delectable et mieulx digne de estre memorisé. Rudimentary as are his gifts (povre et rude entendement), he has picked out (E) the deeds of many of Arthur's knights, and especially those of Lancelot du Lac (F), for it would be a grant peché if they were not remembered. Readers must forgive his crudité et indigestion du langage, and concentrate on plucking les fleurs et les bonnes oudeurs, seeking merely to imitate Lancelot's virtues - although, scenting problems, he hastens to remind his readers $(\mathrm{H})$ that they should as far as possible ignore Lancelot's legieretez ou follies mondaines: he cannot, of course, endorse such detestable and condemnable acts, but he recognises that to err is human (la debilité de humaine condition). And he scuttles back (I) to beg his readers to derive only the most positive lessons from what follows : if they do so, they will themselves acquire louenge et gloire.

Now, none of this should strike any reader of prose-romance prologues as particularly innovative ${ }^{21}$; much of what the prologue of 1488 says is standard fare. The didactic and inspirational value of Arthurian romance is emphasised, for instance, in the prologue to Vérard's 1489 edition of the Tristan ${ }^{22}$; it, like that of the

\footnotetext{
${ }^{21}$ As Cazauran points out, much of the content of prologues is conventional: see «Les romans de chevalerie en France».

${ }_{22}$ Reproduced in facsimile by C. E. Pickford, London, Scolar Press, 1976: «Priant les lecteurs $[. .$.$] qu'il leur plaise excuser mon ignorance ».$
} 
Hystoire du Sainct Greaal ${ }^{23}$, highlights the writer's doubts as to his own capabilities; prologues to the Tristan en prose stress the fact that the story is indubitably voir, ${ }^{24}$ and that it is the writer's duty to record the great deeds of the past $^{25}$. There is, in other words, a process of recombination at work in the prologue to the 1488 edition of the Lancelot en prose : a sort of mix-and-match of perfectly traditional elements, none of which need cause us particular surprise ${ }^{26}$.

Where the study of prologues to the Lancelot becomes intriguing is in a comparison of this prologue with that which Vérard devised for the edition which is undeniably his, the edition of 1494 (see Appendix II) ${ }^{27}$ - and there are, I suggest, two particular centres of interest: just what it is that Vérard deletes in 1494 (which I indicate for the edition of 1488 [Appendix I] by printing in bold only what Vérard reproduces), and the re-ordering, and hence rebalancing, of the message. Let me take first the question of the three major omissions. The first (B), it might be said, is quite simply a redundancy: it embroiders on the citation from St Paul's letter to the Romans $^{28}$ («quaecumque enim scripta sunt ad nostram doctrinam scripta sunt ut per patientiam et consolationem scripturarum spem habeamus » : 15,4) by developing a metaphor itself vaguely biblical, to do with farm-labourers eliminating weeds to allow the good corn to grow. But if we look at this omission in conjunction with another (D), then a rather more interesting picture emerges. This latter omission had been devoted to the writer's embarrassed recognition that not all of Lancelot's deeds could conceivably be presented as good models for the youth of 1488. Lancelot's failings, he says, are the simple result of humaine fragilité ; his virtues far outweigh any deffaulx; he would not dream of approving such acts; he can only throw himself on the mercy of his readers to ask them to excuse the debilite de humaine condition. All this - the weeds, the squirming discomfort - disappears without trace in the prologue of 1494. The latter is unequivocally positive: nothing but triumphalles et glorieuses oeuvres, louenges, glorieux faiz des excellens hommes. It is, of course, uncomfortably positivistic to make assumptions about Vérard's

${ }^{23}$ The author is, he says, «le moindre et le plus petit et est le plus grant pecheur de tous » : published by Jehan Petit, Galliot du Pré and Michel le Noir, Paris, 1516; reproduced in facsimile by C. E. Pickford, London, Scolar Press, 1978.

${ }_{24}$ «Et por ce que je sai bien que ce fu veritez, voudrai je encommencier ...»: Tristan en prose, éd Renée Curtis, Münich, M. Hueber, 1963.

25 «Ce seroit une chose que volentiers orroient povre et riche» : ibid., p. 3.

${ }^{26}$ On this topic, see E. Baumgartner, «La première page dans les manuscrits du Tristan en prose », id., De l'histoire de Troie au Livre du Graal, Orléans, Paradigme, 1994, p. 431-44, and id., «Du manuscrit BnF fr. 103 du Tristan en prose à l'imprimé du Tristan par Jehan le Bourgoys (1489)», Texte et image, éd C. Croisy-Naquet, Ateliers 30/2003 : Cahiers de la Maison de Recherche, Université Charles-de-Gaulle, Lille III, Lille, 2003, p. 11-25.

${ }_{27}$ Winn, by far the best-informed of scholars currently working on Vérard, is convinced that Vérard himself wrote his prologues : see Anthoine Vérard, p. 42-66.

${ }^{28}$ The use of this verse is something of a cliché : in the King James version, «for whatsoever things were written aforetime were written for our learning, that we through patience and comfort of the scriptures might have hope ». As a statement of intent, it is often backed up by another quotation from 2 Timothy 3, 16: «Omnis sciptura divinitus inspirata et utilis ad docendum ad arguendum ad corrigendum ad erudiendum in justitia ». 
motives - but it is difficult to avoid the conclusion that, by 1494, he felt it better not to draw editorial attention to the moral failings of his hero, and better to present the romance as purely inspirational.

The second major omission (D) is, in some ways, more interesting ${ }^{29}$. Here, the writer of the prologue of 1488 introduces a first-person je ... des hystoriographes le mendre. The je has, he tells his readers, been remarkably active on their behalf: he has read very widely in the anciennes escriptures, and been so impressed by the glorious deeds that they record that, excited by their variety (agité de diverses matieres), he has decided to employ his labours (l'encre de [s]on entendement) to perpetuate the memory of the most pleasing. Not-withstanding the parvite $^{30}$ et debile capacité de [s]on povre et rude entendement, he has brought this work to a triumphant conclusion - and he must simply ask his readers $(\mathrm{G})$ to forgive his ignorance and the crudite et indigestion of his native tongue. Now all this is not, of course, to be taken too literally: the modesty topos is conventional enough ${ }^{31}$. "Luces del Gat», the supposed author of the Tristan en prose, apologises for his shaky French; the writer of the prologue to Vérard's 1489 edition of the same romance begs his readers to excuse his ignorance et ... deffaultz; the writer of the prologue to the Hystoire du Sainct Greaal published by Jehan Petit and others in 1516 fears that he may be seen as a maulvais escripvain ${ }^{32}$. And it might simply be that Vérard has realised the commercial dangers of advertising one's incapacities. But I think that more is at stake. The prologue of 1488 , after all, is not just an apology: it is also, as we have seen, an earnest of the writer's studious efforts on behalf of his readers. He has an encyclopaedic knowledge of the repertory of chivalric romance; he has selected, from the stories available, those principalement that best record knightly exercises (l'excercice des armes); the heroes he has elected to put forward are those he has judged deservedly worthy of fame (they have tiltre de longue memoire). In other words, in the edition of 1488, authority and quality are vested, conclusively, in a first-person speaker. Now, this again is perfectly conventional practice: prologues commonly are written by a je-Luce, in the Tristan en prose, is, he says, following his volanté et ... proposement ${ }^{33}$; he is, he says in the prologue to the Tristan in BnF fr. 103, persuaded that his choice of subject-matter will meet with the acclamation of the public; the identity of an anonymous je, in the prologue to the Hystoire du Sainct Greaal, is «revealed» by one of those artfully incomplete concealments that the Middle Ages and the Renaissance so appreciated. It is, in other words, commoner to stress an authorial identity than not to take it into account.

But there is, of course, a je in the prologue to the 1494 Lancelot. This je, however, is not the author/compiler guaranteeing the quality of the work by alluding to his assiduous efforts on the reader's behalf; rather, as the prologue opens, he is

\footnotetext{
${ }^{29}$ Also analysed by Winn, Anthoine Vérard, p. 301.

30 «Insufficiency, meanness»: see Godefroy, Dictionnaire de l'ancienne langue française, VI, 16a, with a number of Renaissance instances.

31 And cf. the remarks of Baumgartner, «Du manuscrit BnF fr. 103 ... à l'imprimé du Tristan », p. 14-15, who also reproduces (ibid., p. 18) the prologue itself.

${ }^{32}$ For details of these editions, see footnotes 21-23 above.

${ }^{33}$ Tristan en prose, éd Curtis.
} 
the publisher, underlining his admiring and commercially valuable relationship with one reader in particular, King Charles VIII. Charles, says Vérard, is an avid recreational reader of chivalric deeds, which are, like the king's own chevalereux couraige, an example to all the young noblemen of his court ; thus, by a convenient editorial sleight of hand - flattery by metonymy, as it were - Vérard elides Lancelot's valiant deeds with Charles's. What is interesting is the fact that the miniature which Vérard has had specially devised for this exemplar in particular (fig. 1) performs that same beguiling elision ${ }^{34}$. Commonly, as Claudin and Winn have shown ${ }^{35}$, in the presentation miniatures in his de luxe copies, Vérard places himself as donor, very recognisably, centre-stage; here, by contrast, he presents himself in a most gratifyingly intimate little tête-à-tête with the king, perched on a balcony, presenting this very copy to its primary reader. Below the pair of them is a pleasingly ambiguous tournament: are these intrepid jousters to be understood as Lancelot and his companions? Or as Charles's jeunes nobles chevaliers? Are the courtiers leaning from their stand, transfixed by the prowess of the tournament, Charles's? or Arthur's? Is the tournament to be understood as real? or as a manifestation of the chivalry of which the Lancelot en prose is the repository? There is, of course, no answer to these questions - but it is difficult to avoid the conclusion that the King and Vérard are being exhibited to readers in the same light as is adumbrated in the prologue to the 1494 edition: as colluding, publisher and king, in this ambitious chivalric enterprise ${ }^{36}$.

And, of course, the verse prologue too (Appendix III) - also devised, it seems, exclusively for the presentation copy - perhaps designedly slurs the distinction between fiction and actuality, Charles's court and Arthur's. It is, as I said, something of a virtuoso piece, with its emblematisation of the king's name something common enough in late-medieval and Renaissance encomiastic poetry ${ }^{37}$.

34 That is, for the presentation copy for Charles VIII, BnF Rés. Vélins 614-616. It is reproduced in colour in Claudin, Histoire de l'imprimerie, t. II, p. 463, and also by Winn, Anthoine Vérard, fig. 5.7a, p. 311. Winn considers that this miniature, and others in the presentation volume, were prepared by the so-called Master of Jacques de Besançon, "although they are much coarser in style than his best work»; she refers the reader to P. Durrieux, Un Grand enlumineur parisien au XVe siècle, Jacques de Besançon et son oeuvre, Paris, Champion, 1892, p. 92-93 ; on Jacques, see also E. Spencer, « Dom Louis de Busco's Psalter», Gatherings in Honor of Dorothy E. Miner, ed. U. McCracken et al., Baltimore, Walters Art Gallery, 1974, p. 227-40.

${ }_{35}$ Claudin, Histoire de l'imprimerie, II, p. 395, 466, and Winn, Anthoine Vérard, passim, but especially ch. 4, p. 101-205.

36 In another presentation copy, printed on vellum (BnF Rés. Vélins 617), Vérard includes a different full-page presentation miniature, reproduced in colour in Histoire de l'édition française I : Le Livre conquérant, pl. 39, and in black and white, Winn, Anthoine Vérard, p. 313. This latter shows - and again there is a merging of the chivalric identities of Charles VIII and the Arthurian world - Vérard in his characteristic robe presenting his Lancelot en prose to the king as he is about to go into battle.

${ }^{37}$ See P. Zumthor, Le Masque et la lumière: la poétique des grands rhétoriqueurs, Paris, Seuil, 1978, p. 216, 250-52, and F. Rigolot, Poétique et onomastique, Geneva, Droz, 1977, p. $30-35$. 
Take, for instance, the opening stanza which seems at first reading to be a eulogy of knighthood - perhaps, we think, a eulogy of the hero of the book we, and Charles, are about to read - but which comes ultimately, perhaps, to be a sententious lesson in kingship. A true knight, possessing all true knightly couraige, is always eager to enter into combat; the chevalier paoureux, with no spirit of adventure, will never possess bons vassaulx. That first stanza is emblematic of the remainder of the poem - the argument of which is, if convoluted, perfectly plain: Charles should furnish his mind with the nobles meurs which he will find extensively described in this very book; kingship requires the ability to pursue justice, equity and truth - all of which are displayed among those of the Round Table; Lancelot was the very image of the gentil[s] errant[s] of the Round Table, and therefore a pattern-book for Charles himself; Vérard is performing a service specifically to kingship in making sure that Lancelot's deeds are available for emulation.

Now it is worth noting that this verse prologue is included in only one surviving copy of the Lancelot en prose: Vélins 614, which was prepared specifically for Charles, and which also includes the specially commissioned miniature that I described earlier, with Charles and Vérard to be seen in the upper left. This miniature is, as far as I have been able to discover, unexampled in any other of Vérard's editions, and the marketing «message» that it conveys seems extremely interesting. I suggested earlier that it blurs the distinction between Charles's chivalry and Arthur's : that is, that it is unclear to the reader if we are to take it we are witnessing a late-medieval tournament under Charles, or an illustration of Lancelot's prowess. But what is particularly remarkable, here, is another feature: the way that the little scene in the upper left implies an intimacy, almost a complicity, between Vérard and Charles. Charles is dressed in full ceremonial dress: crowned and furred and bejewelled, against a background of fleurs de lis; Vérard is dressed in his characteristic plain robe, bare-headed ; the king is about to receive the Lancelot from the publisher's own hand. Crucially, the two of them are alone : the courtiers, if they are Charles's, are perched on a quite separate stand, their attention focused entirely on the tournament below. And what is significant is precisely that: the king and the publisher so isolated from the remainder of the court. I have been unable to look at all of Antoine Vérard's editions - he was remarkably prolific - but I have been unable to discover any other presentation miniature where any such intimacy is implied: in every other such miniature where Vérard is shown presenting his work specifically to the king or to a royal or noble court, a little group of courtiers is in interested attendance ${ }^{38}$. Any other but one: a presentation miniature designed for a vellum copy of the Vigiles des morts, which Vérard published between 1496 and 1498, and for which a copyspecific miniature has been commissioned ${ }^{39}$. Here, the miniature shows Vérard on his knees, presenting a copy to what is probably Charles, with, in the background, a corpse lying on a shroud and a nimbus embracing God, the Virgin Mary and two

\footnotetext{
${ }^{38}$ Presentation miniatures are reproduced extensively by Claudin, McFarlane, and especially by Winn.

${ }^{39}$ On which see Winn, Anthoine Vérard, p. 451-56; the copy concerned is Chantilly Musée Condé 1956 (XII.F.44). There is a verse prologue, but Winn concludes that it is not by Vérard himself; she also expresses doubts as to whether this is indeed Charles.
} 
angels carrying what is presumably the soul of the dead man. But it is, of course, the essence of the devotional book, and especially of meditation on death and dying, that it is individual: to come face-to-face with death is to come face-to-face with one's own mortality; it is also, of course, directly and unashamedly didactic, and therefore requires the individual response. To find a similar image of intimacy in what is something fictional and public is remarkable - but it is, surely, precisely what the 'conversation' of the verse prologue implies: Vérard is, he suggests, generously providing a specific and individually appropriate model for Charles, supplying what Charles needs : examples of the sort of noble vouloir, and ouvraige parfaiz of which a roy bien regnant should be urgently aware. The miniature, I suggest, underlines the message of the verse prologue carefully devised by Vérard : that he, Vérard, as a libraire, is privileged to select for Charles not just what may please him, but also what he personally seems to diagnose as necessary for the king.

At the outset of this article, I suggested that what we might be examining was Vérard's « sales strategy » - and I have several times used terms that might seem just as anachronistic. I would defend them, however, because I contend, in the wake of Brown, Winn and Armstrong, that this most successful of publishers was indeed as adept as any modern publisher in the sales methods which ensured commercial success in a difficult and challenging market: sales success with a new readership, and one with which royal patronage was an essential marketing tool. Here, I scrape barely the surface; it would be my hope that in the long term, and as Ménard has advocated, a full-scale overall study might make it possible for us to understand the role that the publishers - risk-taking, undaunted by the immensity of their sourcetexts - played in the perpetuation of the romances of the Middle Ages into the very different world of the Renaissance and beyond. 


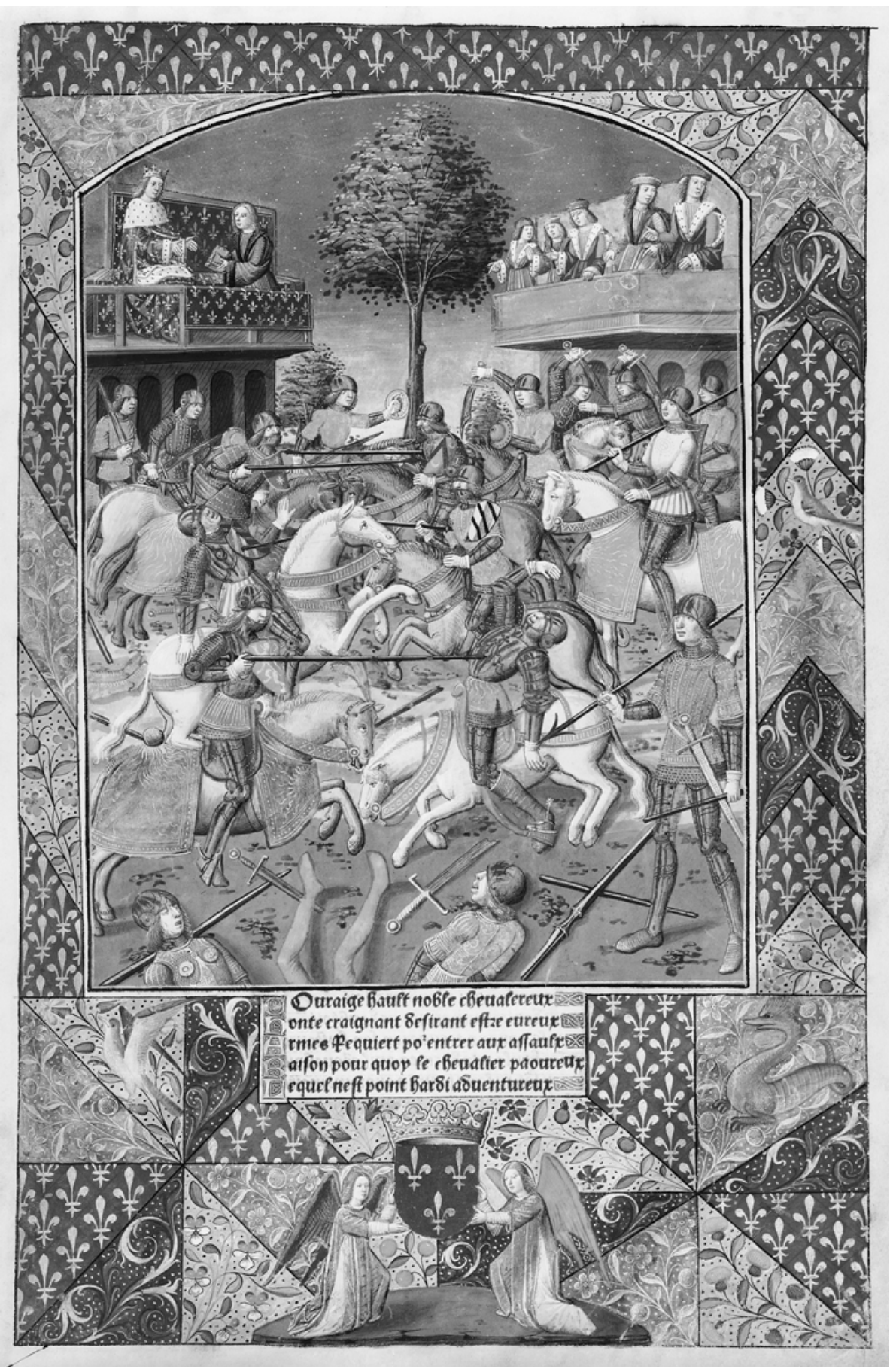




\begin{abstract}
APPENDIX I
Prose prologue to the edition of 1488, transcribed from facsimile by C. E. Pickford, London, The Scolar Press, 1977. Segments retained, more or less verbatim, for the edition of 1494 are in bold.
\end{abstract}

A [C]ombien que les anciennes histoires ne sont pas de pareille foy que sont les sainctes et divines escriptures approuvees en la cristienne Loy, si n'est ce pas que les faiz et gestes memorisez et racomptez en icelles ne soient veritables et advenues. Et se les paiens eu cours de leur regne et pour le temps de leurs folles et imparfaictes credences ont voulu deifier, tenir et reputer comme dieux aucuns hommes vertueux, pour leurs triumphalles et glorieuses oeuvres, il est bien decent et raisonnable que entre les crestiens, les vertus et glorieux faiz des excellentz hommes vivent aprez mort, et soient aux successeurs en perpetuelle memoire, et que a chascun soit fait memorial condigne selon ses valeur, merite et estat, aux ungz par sculptures et descriptions sur leurs monuementz, et aux autres par rediger en volumes leurs excellences, triumphes et operations, qui sont et demeurent a tousjours en bon exemple aux lecteurs et aux auditeurs, car ce qui y est recité de bien et de vertu est ensaignement et excitation de bien et vertueusement vivre, pour en acquerir renommee perpetuelle entre les hommes oultre l'esperee remuneration eternelle, et ce que l'en y treuve de mal ou vice est a execration, et pour reprimer la temerité des mauvais et vicieux. Et comme tesmongne l'appostre saint Paul, toutes les choses qui sont escriptes sont a nostre doctrine : c'est a entendre que nous debvons

B imiter les vertus et bonnes oeuvres, fuyr et eviter les vices.

Et ainsi que font les bons et songneux laboureurs, qui extirpent en saison les chardons et autres mauvaises herbes de entre les bons grains et semences, il nous convient de jetter et mettre arriere les choses reprouchables et nuysibles, contraires a vertu, et de tout nostre cueur ensuyvre et excercer

C ce qui peult mener a l'estat de perfection et de honneur. Or est ainsi que des hommes qui es jours anciens ont eu distribution des dons de Dieu et de nature, les ungz ont appliqué leur esperit, mise leur cure et employé leur temps a estude en diverses facultés, et puys ont composé traictez et volumes a l'edification d'autruy, par lesquelz leur memoire a esté perpetuelle entre les hommes, et permaindra jusques a la consummation des siecles. Les autres ont excercé leurs corps aux armes et a faire prouesses et chevaleries, et ont triumphé en multiplication de glorieuses victoires, en quoy ilz ont merité et desservi que leurs vertueux faiz aient esté recueilliz et mis par escript en volumes autentiques pour obtenir lieu de perpetuité et demourer a tousjours en la memoire des vivans, a fin que par la frequence de la lecture et recordation d'iceulx les courages des jeunes nobles bacheliers desirans florir en renommee chevalereuse et accroistre leur noblesse soient instruiz et excitez a vertueusement travailler et ouvrer 
en leur estat, a l'exemple de ceulx dont ilz voient et oyent la renommee vivre longuement et sans deffaillir aprez leur mort.

D Pour ces causes je qui suis des hystoriographes le mendre, aprez la revolution et lecture de plusieurs anciennes escriptures et hystoires, entre lesquelles se sont presentez devant mes yeulx les faiz et oeuvres vertueux de plusieurs nobles chevaliers qui pour los et honneur acquerre s'estoient en leurs jours efforcez de vaincre les victoriens et tollir le nom aux plus et mieulx renommez, pour par sur tous triumpher en victoire glorieuse, ay fiché l'encre de mon entendement et agité de diverses matieres en lieu qui m'a semblé plus delectable et mieulx digne de estre memorisé, a l'exaltation de noblesse et de chevalerie et a l'edification et exemple de toutes gens, et de ceulx principalement qui en l'excercice des armes desirent parvenir a la haultesse de honneur, et acquerir tiltre de longue memoire. Et a ceste fin ay compilé, a telz labeurs que la parvité et debile capacité de mon povre et rude entendement a peu soustenir et porter,

E ung livre extraict de plusieurs et diverses [ed. diveses] hystoires traictant de plusieurs fais et merveilleuses chevaleries avenues au temps du tresnoble et preux chevalier Artus, roy de la Grant Bretaigne, qui estoit seigneur et gardain de la Table Ronde, de laquelle et des vaillans chevaliers qui en furent compaignons tante et telle renommee a couru parmy le monde que elle n'en sera jamais estaincte, specialement du tresvertueux chevalier Lancelot du Lac, filz du noble roy Ban de Benoic,

F duquel les puissans faiz, les excellentes chevaleries et la renommee glorieuse moult semble de telle qualité, si fructueux et de si digne commemoration que a mon aviz grant peché seroit et perte irreparable de les souffrir perir et estaindre par omission de les escripre et les rediger en volume. Et de tant que je les ay trouvés exceller et passer tous les autres en toutes manieres, ay je plus insisté a la memorization et narration d'iceulx en mon livre, lequel principalement ay dedié et composé a son nom et a sa louenge et gloire, ensemble les autre suppotz de ladicte Table Ronde dont il fut compaignon et chevalier tresrenommé en bonté de

G chevalerie. Si supplie a tous ceulx qui liront et orront mondit livre qu'il leur plaise premierement excuser mon ignorance et supplier a la crudité et indigestion du langage qui est gros et maternel, et singulierement cueillir et prendre les fleurs et les bonnes oudeurs qu'ilz y trouveront, en soy conformant par imitation aux bonnes oeuvres et glorieuses vertus qui

H florissoient et abundoient en icelui noble chevalier Lancelot du Lac sans avoir regart ou soy gaires arrester en aucunes legieretez ou follies mondaines, esquelles il se abandonna par humaine fragilité, car l'excellence et la quantité de ses faiz tant glorieux excedent tous les deffaulx dont on le pourroit arguer ou reprendre. Et on sçait bien que soy abstenir de tout pechié est chose plus divine que humaine; toutesfois je ne vueil pas approuver les vices que chacun doit detester et blasmer, mais seullement, tant comme il est permis, excuser la debilité de humaine condition. Et speciallement je prie tous jeunes nobles desireux de vertu et de honneur, pour lesquelz j'ay principalement entreprins ce present

I labeur, qu'ilz en cueillent et goustent le fruit et facent que mon oeuvre vaille et 
fructifie en eulx tellement que par leur bien faire a l'exemple dudit chevalier Lancelot et des autres vaillans hommes dont les faiz sont racomptez en mon livre, ilz acquierent en leurs vies louenge et gloire de bonne chevalerie, dignes de immortelle memoire.

\begin{abstract}
APPENDIX II
Vérard's prose prologue to his 1494 edition of the Lancelot en prose, transcribed from Lyon, Bibliothèque Municipale ms. 5046. Segments retained from the editio princeps of 1488 are given in bold.

Considerant que par les triumphalles et glorieuses oeuvres que les vaillans hommes et nobles chevaliers anciennement firent en fait de chevalerie acquirent en leurs vies louenges et gloire de perpetuelle memoire, je vostre treshumble et tresobeissant serviteur a l'honneur et louenge de vous, mon tresredoubté et souverain seigneur, chief de toute noblesse et chevalerie, Charles, huitiesme de ce nom, trescrestien roy de France, affin que vostre chevalereux couraige et des jeunes nobles chevaliers desireux de vertu et honneur a l'exemple de vous, lisans par maniere de recreation les hystoyres et faiz des anciens vaillans chevaliers, soit de plus en plus multiplié en triumphe et valeur, vous ay fait ces presens volumes de la Table Ronde, traictans de plusieurs faiz et merveilleuses chevaleries advenues au temps du tresnoble et preux chevalier Artus, Roy de la Grant Bretaigne, qui estoit seigneur et gardien de la dicte Table Ronde, de laquelle et des vaillans chevaliers qui en furent compaignons en est et a esté telle renommee parmy le monde qu'elle n'en sera jamais estaincte; speciallement du tresvertueux chevalier Lancelot du Lac, filz du noble roy Ban de Benoic, duquel les puissans faiz, les excellentes chevaleries et la renommee glorieuse excedent et passent tous les aultres suppostz de ladicte Table Ronde dont il fut compaignon et chevalier tresrenommé en bonté de chevalerie. Au nom duquel louenge et gloire sont faitz et composez cesditz presens volumes. Et combien que les anciennes histoires ne sont pas de pareille foy que sont les sainctes et divines escriptures approuvees en la crestienne loy, si n'est ce pas que les faiz et gestes memorisez et racomptez en icelles ne soient veritables et advenus. Se les payens ou cours de leur regne et pour le temps de leurs folles et imparfaictes credences ont voulu deifier, tenir et reputer comme dieux aulcuns hommes pour leurs glorieuses et vertueuses operations, il est bien decent et raisonnable que entre les crestiens les vertus et glorieux faiz des excellens hommes vivent aprés la mort et soient aux successeurs en perpetuelle memoire, et que a chascun soit fait memorial condigne selon ses valeur, merite et estat: aux ungs que par sculptures et descriptions sur leurs monumens, et aux aultres par rediger en volumes et escript leurs excellences, triumphes et operations qui sont et demourent a tousjours en bon exemple aux lecteurs et aux auditeurs, car ce qui est recité de bien et de vertu est enseignement et excitation de bien et vertueusement vivre pour en acquerir renommee perpetuelle entre les hommes, oultre l'esperee
\end{abstract}


remuneration eternelle, et ce que l'en y trouve de mal ou vice est excecration et pour reprimer la temerité des mauvais et vicieux. Et comme tesmoigne l'apostre sainct Paul, toutes les choses qui sont escriptes sont a nostre doctrine : c'est a entendre que nous devons imiter les vertus et bonnes oeuvres, fuyr et eviter les vices. Or est ainsi que des hommes qui es jours anciens ont eu distribution des dons de Dieu et de nature, les ungs ont appliqué leur esperit, mise leur cure et employé leur temps a estudes en diverses facultez, et puis ont composé traictez et volumes a l'ediffication d'autruy, par lesquelz leur memoire est perpetuelle entre les hommes ; les aultres ont excercé leurs corps aux armes et a faire proesses et chevaleries, et ont triumphé en multiplication de glorieuses victoires en quoy ilz ont merité et desservy que leurs vertueux faiz ayent esté recueilliz et mys par escript en volumes auctenticques pour obtenir lieu de perpetuité et demourer a tousjours en la memoire des vivans, affin que par la frequentacion de la lecture et recordacion d'iceulx les couraiges des jeunes nobles bacheliers desirans florir en renommee chevalereuse et acroistre leur noblesse soient instruitz et excitez a vertueusement travailler et ouvrer en leur estat, a l'exemple de ceulx dont ilz voyent et oyent la renommee vivre longuement et sans deffaillir aprés leur mort, et principallement dudit chevalier Lancelot dont les faitz sont cy racomptez dignes de immortelle memoire.

\section{APPENDIX III}

Verse prologue to the edition of 1494, in BnF Rés. Vélins 614 (taken from Winn, Anthoine Vérard,, pp. 295-6 (punctuation slightly emended).

Couraige hault, noble, chevalereux,

Honte craignant, desirant estre eureux,

Armes requiert pour entrer aux assaulx -

Raison pourquoy le chevalier paoureux,

Lequel n'est point hardi, adventureux

En faiz d'armes n'a jamais bons vassaulx.

Souverain Roy, haultain chief des royaulx,

De nobles meurs vostre couraige emplez

Et les beaulx faiz des nobles contemplez;

Vous les verrez en ce livre, chier Sire,

Au plain escripz, s'il vous plaist a y lyre ;

La trouverez faiz de chevalerie,

Les grans assaulx de la gendarmerie

Ou les lasches sont demeurez au bac ;

Icy tous bruitz verrez de seigneurie

Signantement de Lancelot du Lac.

Regne tenir est une dignité

Ou tout honneur et toute gravité

Yeulx esclarcis doivent tousjours avoir, 
Droit regardant le chemin d'equité En soustenant justice et verité,

Faisant raison sans flechir pour avoir.

Roy bien regnant doit entendre et sçavoir Aymer armes et monstrer en ses faiz

Noble vouloir, par ouvraige parfaiz,

Comme plusieurs chevaliers de ce monde

Expressement ceulx de la Table Ronde.

Honneur acquist Lancelot le vaillant, Vray chevalier d'armes bien bataillant,

Joustes faisant et cent choses nouvelles ;

Toujours dehait comme gentil errant,

Joyeulx d'esprit, prenant et assaillant

En toutes pars tours, chasteaulx et tourelles,

Sur tous autres plaisans aux damoiselles,

Moriginé, gracïeulx, amiable

En ditz, en faitz advenant, honnorable,

De tous aymé, ouÿ et escouté

Et d'autre part en armes fort doubté,

Comme celuy qui a doubter estoit

Et qui d'entrer aux armes ne doubtoit ;

Nous le pouons trouver en son hystoyre

Ou les hauls pris d'armes qu'il conquestoit

Mis cy sont au long pour en avoir memoire. 